\title{
Inter-annual variability of the carbon dioxide oceanic sink south of Tasmania
}

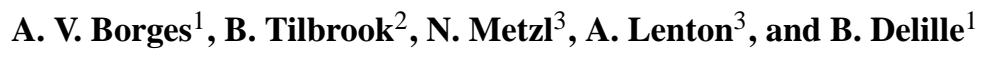 \\ ${ }^{1}$ Unité d'Océanographie Chimique, Interfacultary Center for Marine Research, Université de Liège, Institut de Physique (B5), \\ 4000 Liège, Belgium \\ ${ }^{2}$ Wealth from Oceans Flagship, Commonwealth Scientific and Industrial Research Organisation, and Antarctic Climate and \\ Ecosystem Cooperative Research Centre, PO Box 1538, Hobart, TAS 7001, Australia \\ ${ }^{3}$ Laboratoire d'Océanographie et du Climat: Expérimentations et Approches Numériques, Institut Pierre Simon Laplace, \\ CNRS-UMR 7159, Université Pierre et Marie Curie, Case 100, 4 Place Jussieu, 75252 Paris Cedex 5, France
}

Received: 28 September 2007 - Published in Biogeosciences Discuss.: 11 October 2007

Revised: 20 December 2007 - Accepted: 10 January 2008 - Published: 6 February 2008

\begin{abstract}
We compiled a large data-set from 22 cruises spanning from 1991 to 2003, of the partial pressure of $\mathrm{CO}_{2}$ $\left(\mathrm{pCO}_{2}\right)$ in surface waters over the continental shelf $(\mathrm{CS})$ and adjacent open ocean $\left(43^{\circ}\right.$ to $46^{\circ} \mathrm{S} ; 145^{\circ}$ to $\left.150^{\circ} \mathrm{E}\right)$, south of Tasmania. Climatological seasonal cycles of $\mathrm{pCO}_{2}$ in the $\mathrm{CS}$, the subtropical zone (STZ) and the subAntarctic zone (SAZ) are described and used to determine monthly $\mathrm{pCO}_{2}$ anomalies. These are used in combination with monthly anomalies of sea surface temperature (SST) to investigate inter-annual variations of SST and $\mathrm{pCO}_{2}$. Monthly anomalies of SST (as intense as $2^{\circ} \mathrm{C}$ ) are apparent in the CS, STZ and SAZ, and are indicative of strong inter-annual variability that seems to be related to large-scale coupled atmosphere-ocean oscillations. Anomalies of $\mathrm{pCO}_{2}$ normalized to a constant temperature are negatively related to SST anomalies. A reduced winter-time vertical input of dissolved inorganic carbon (DIC) during phases of positive SST anomalies, related to a poleward shift of westerly winds, and a concomitant local decrease in wind stress is the likely cause of the negative relationship between $\mathrm{pCO}_{2}$ and SST anomalies. The observed pattern is an increase of the sink for atmospheric $\mathrm{CO}_{2}$ associated with positive SST anomalies, although strongly modulated by interannual variability of wind speed. Assuming that phases of positive SST anomalies are indicative of the future evolution of regional ocean biogeochemistry under global warming, we show using a purely observational based approach that some provinces of the Southern Ocean could provide a potential negative feedback on increasing atmospheric $\mathrm{CO}_{2}$.
\end{abstract}

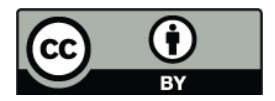

Correspondence to: A. V. Borges (alberto.borges@ulg.ac.be)

\section{Introduction}

The ocean is a major and dynamic sink for anthropogenic $\mathrm{CO}_{2}$ (e.g. Sabine et al., 2004) playing an important role in the mitigation of climate change. The inclusion in climate models of potential feedbacks of air-sea $\mathrm{CO}_{2}$ fluxes on the increase of atmospheric $\mathrm{CO}_{2}$ is required to improve the reliability of the predictions of the future evolution of the global carbon cycle and climate change. The collection of partial pressure of $\mathrm{CO}_{2}\left(\mathrm{pCO}_{2}\right)$ data for surface waters during the last 30 years has allowed the investigation and characterisation of changes in air-sea $\mathrm{CO}_{2}$ fluxes on decadal scales in some regions of the open ocean (e.g., North Atlantic Ocean (Lefèvre et al., 2004; Corbière et al., 2007; Bates, 2007), Pacific Ocean (Feely et al., 2006; Midorikawa et al., 2006; Takahashi et al., 2006), and Southern Ocean (Inoue and Ishii, 2005)). These studies have described how $\mathrm{pCO}_{2}$ in surface waters and the associated air-sea $\mathrm{CO}_{2}$ fluxes are evolving, and provide data to constrain and understand feedbacks in the carbon cycle related to changes in oceanic physical and biogeochemical processes.

The investigation of long term trends in surface water $\mathrm{CO}_{2}$ requires the description of the inter-annual variability of $\mathrm{pCO}_{2}$. The main drivers of the inter-annual variability of surface $\mathrm{pCO}_{2}$ described to date are large-scale atmosphereocean coupled climate oscillations including the El Niño Southern Oscillation (ENSO) for the equatorial and subtropical Pacific Ocean (Feely et al., 2002; Dore et al., 2003; Brix et al., 2005), and the North Atlantic Oscillation for the North Atlantic Ocean (Gruber et al., 2002). In the Southern Ocean, atmosphere-ocean coupled climate oscillations such as the Southern Annular Mode (SAM) and ENSO have been identified using biogeochemical ocean general circulation models as major drivers of inter-annual variability of $\mathrm{pCO}_{2}(\mathrm{Le}$

Published by Copernicus Publications on behalf of the European Geosciences Union. 


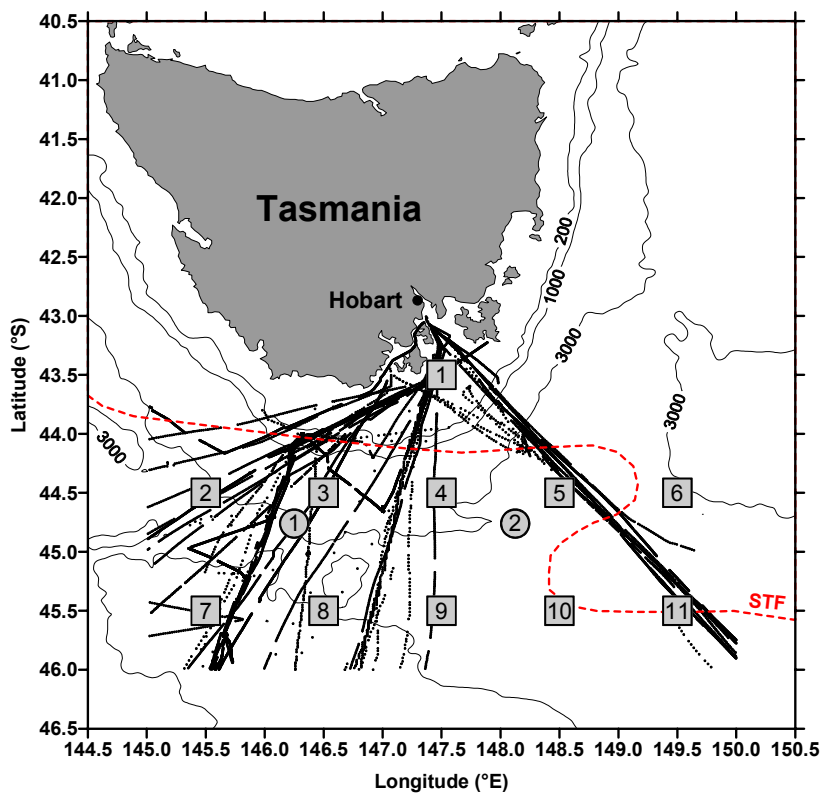

Fig. 1. Map showing ship tracks, bathymetry based on the Smith and Sandwell (1997) global seafloor topography, the climatological position of sub-tropical front (STF) based on Belkin and Gordon (1996) and Hamilton (2006), grid nodes from the Reynolds et al. (2002) sea surface temperature monthly climatology (squares), and the grid nodes of the Kalnay et al. (1996) National Centers for Environmental Prediction daily wind speeds (circles).

Quéré et al., 2007; Lenton and Matear, 2007; Lovenduski et al., 2007; Verdy et al., 2007).

Due to the relative scarcity of $\mathrm{pCO}_{2}$ field data in the Southern Ocean, the inter-annual variability of air-sea $\mathrm{CO}_{2}$ fluxes has seldom been investigated from a purely observational based approach. The impact of warm anomalies on air-sea $\mathrm{CO}_{2}$ fluxes in the Southern Ocean has to some extent been investigated using cruise-to-cruise comparisons (Jabaud-Jan et al., 2004; Brévière et al., 2006). These two studies show that warm anomalies lead to significant, but opposing, effects on air-sea $\mathrm{CO}_{2}$ fluxes in different regions of the high latitude Southern Ocean. This could be due to the spatially heterogeneous control of export production through either light or nutrient limitation in the Southern Ocean (Le Quéré et al., $2000,2002,2003$ ), with some modulation by thermodynamic effects of sea surface temperature (SST) change on $\mathrm{pCO}_{2}$.

The aim of the present work is to investigate at different time scales the variations of $\mathrm{pCO}_{2}$ in the surface waters of the continental shelf (CS) and adjacent open ocean $\left(43^{\circ}\right.$ to $46^{\circ} \mathrm{S}$; $145^{\circ}$ to $150^{\circ} \mathrm{E}$ ) south of Tasmania, based on a compilation and synthesis of 40 transects obtained during 22 cruises (Fig. 1, Table 1). We first compose and describe the climatological seasonal cycles of $\mathrm{pCO}_{2}$ in the $\mathrm{CS}$, the subtropical zone (STZ) and the subAntarctic zone (SAZ). We then proceed to investigate the inter-annual variability of SST and $\mathrm{pCO}_{2}$, using monthly anomalies to deseasonalize the data- sets. We also examine the relationship between anomalies in air-sea $\mathrm{CO}_{2}$ fluxes and SST on inter-annual time scales to provide insights into the biogeochemical responses of midlatitudes of the Southern Ocean to global warming.

\section{Methods}

Measurements of $\mathrm{pCO}_{2}$ were obtained with the equilibration technique as described by Frankignoulle et al. (2001) for the Université of Liège (ULg), by Lenton et al. (2006) for Commonwealth Scientific and Industrial Research Organisation (CSIRO), and by Poisson et al. (1993) for Laboratoire d'Océanographie et du Climat: Expérimentations et Approches Numériques/Institut Paul Simon Laplace (LOCEAN/IPSL). CSIRO and LOCEAN/IPSL systems were inter-calibrated during the R.V. Meteor international at-sea intercomparison (06/06-19/06/1996) in the North Atlantic (Körtzinger et al., 2000), and the results showed that the $\mathrm{pCO}_{2}$ data were consistent within $\pm 1 \mu \mathrm{atm}$. ULg and LOCEAN/IPSL systems were inter-calibrated during the OISO3 cruise (21/12-28/12/1998) in the central Indian sector of the Southern Ocean, and the results showed that the $\mathrm{pCO}_{2}$ data were consistent within $\pm 4 \mu \mathrm{atm}$. ULg and CSIRO systems were inter-calibrated during the AA0301 cruise (11/10 27/10/2003) in eastern Indian sector of the Southern Ocean, and the results showed that the $\mathrm{pCO}_{2}$ data were consistent within $\pm 5 \mu \mathrm{atm}$. Since $82 \%$ of the data were obtained by one single group (CSIRO; Table 1), we assume the uncertainty of the whole data-set to be better than $\pm 3 \mu \mathrm{atm}$. All data were converted to $\mathrm{pCO}_{2}$ in wet air at $1 \mathrm{~atm}$. During the time-span of the data-set (from 1991 to 2003), atmospheric $\mathrm{pCO}_{2}$ increased by $20 \mu \mathrm{atm}\left(1.7 \mu \mathrm{atm} \mathrm{yr}^{-1}\right)$. Based on four cruises carried out between 1969 and 2002, Inoue and Ishii (2005) showed that $\mathrm{pCO}_{2}$ in surface waters in the STZ and SAZ near Tasmania increases at a rate very close to the increase of atmospheric $\mathrm{CO}_{2}$. Hence, data were referenced to 1997, the middle of the time-series, according to:

$\mathrm{pCO}_{2 \text { sea } 1997}=\mathrm{pCO}_{2 \text { sea year }}+\left(\mathrm{pCO}_{2 \text { air 1997 }}-\mathrm{pCO}_{2 \text { air year }}\right)(1)$

where $\mathrm{pCO}_{2 \text { sea } 1997}$ is the $\mathrm{pCO}_{2}$ in seawater referenced to $1997, \mathrm{pCO}_{2}$ sea year is the $\mathrm{pCO}_{2}$ in seawater from a given year, $\mathrm{pCO}_{2}$ air 1997 is the atmospheric $\mathrm{pCO}_{2}$ in 1997 , and $\mathrm{pCO}_{2}$ air year is the atmospheric $\mathrm{pCO}_{2}$ for the same given year.

Atmospheric $\mathrm{pCO}_{2}$ data from the Cape Grim station $\left(40.7^{\circ} \mathrm{S}, 144.7^{\circ} \mathrm{E}\right.$; Tasmania) were obtained from the Cooperative Air Sampling Network of the National Oceanic and Atmospheric Administration/Earth System Research Laboratory/Global Monitoring Division (http://www.cmdl.noaa. gov/). Hereafter, $\mathrm{pCO}_{2}$ refers to $\mathrm{pCO}_{2 \text { sea } 1997}$.

Air-sea $\mathrm{CO}_{2}$ fluxes were computed according to:

$F=k \alpha \Delta \mathrm{pCO}_{2}$

where $F$ is the air-sea $\mathrm{CO}_{2}$ flux, $k$ is the gas transfer velocity, $\alpha$ is the $\mathrm{CO}_{2}$ solubility coefficient, and $\Delta \mathrm{pCO}_{2}$ is the 
Table 1. Cruises, ships, institutes, dates (dd/mm/yyyy) of transects in the continental shelf (CS), the subtropical zone (STZ) and the subAntarctic zone (SAZ) south of Tasmania.

\begin{tabular}{|c|c|c|c|c|c|c|}
\hline Cruise & ship & institutes & date & $\mathrm{CS}$ & STZ & SAZ \\
\hline \multirow{2}{*}{ V191 } & \multirow{2}{*}{ R.S.V. Aurora Australis } & \multirow{2}{*}{ CSIRO } & 05/10/1991 & + & + & + \\
\hline & & & $25 / 10 / 1991$ & + & + & + \\
\hline V192 & R.S.V. Aurora Australis & CSIRO & $21 / 11 / 1992$ & + & & \\
\hline \multirow{2}{*}{ V792 } & \multirow{2}{*}{ R.S.V. Aurora Australis } & \multirow{2}{*}{ CSIRO } & 05/01/1993 & + & + & \\
\hline & & & 07/03/1993 & + & + & + \\
\hline \multirow{2}{*}{ V993 } & \multirow{2}{*}{ R.S.V. Aurora Australis } & \multirow{2}{*}{ CSIRO } & $12 / 03 / 1993$ & + & + & + \\
\hline & & & 08/05/1993 & + & + & + \\
\hline \multirow{2}{*}{ V193 } & \multirow{2}{*}{ R.S.V. Aurora Australis } & \multirow{2}{*}{ CSIRO } & 07/08/1993 & + & + & + \\
\hline & & & 08/10/1993 & + & + & + \\
\hline \multirow{2}{*}{ V493 } & \multirow{2}{*}{ R.S.V. Aurora Australis } & \multirow{2}{*}{ CSIRO } & $19 / 11 / 1993$ & + & & + \\
\hline & & & $27 / 12 / 1993$ & + & & + \\
\hline \multirow{2}{*}{ AA9407 } & \multirow{2}{*}{ R.S.V. Aurora Australis } & \multirow{2}{*}{ CSIRO } & 02/01/1994 & + & + & + \\
\hline & & & 28/02/1994 & + & + & + \\
\hline AA9401 & R.S.V. Aurora Australis & CSIRO & $31 / 08 / 1994$ & + & + & + \\
\hline \multirow{2}{*}{ AA9404 } & \multirow{2}{*}{ R.S.V. Aurora Australis } & \multirow{2}{*}{ CSIRO } & $13 / 12 / 1994$ & + & + & + \\
\hline & & & $31 / 01 / 1995$ & + & + & + \\
\hline \multirow{2}{*}{ AA9501 } & \multirow{2}{*}{ R.S.V. Aurora Australis } & \multirow{2}{*}{ CSIRO } & $18 / 07 / 1995$ & + & + & + \\
\hline & & & $07 / 09 / 1995$ & + & & + \\
\hline SS9511 & R.V. Southern Surveyor & CSIRO & $23 / 11 / 1995$ & + & & + \\
\hline \multirow{2}{*}{ AA9604 } & & & $19 / 01 / 1996$ & + & & + \\
\hline & R.S.V. Aurora Australls & CSIRU & $30 / 03 / 1996$ & + & + & + \\
\hline AA 9601 & $R S V$ Aurora Australis & & $22 / 08 / 1996$ & + & + & + \\
\hline AА9001 & R.S.V. Aurora Australts & CSIRU & 20/09/1996 & + & + & + \\
\hline MINERVF38 & SV Astrolahe & I OCFAN/IPSI & $21 / 10 / 1996$ & + & + & + \\
\hline MINERVE38 & S.V. Astrolabe & LUCEAN/IPSL & 23/11/1996 & + & + & + \\
\hline MINERVE39 & SV Astrolahe & & 02/02/1997 & + & + & + \\
\hline & S.V. Astrolabe & LOCEAN/IPSL & $17 / 02 / 1997$ & & + & \\
\hline AA9703 & & & $14 / 11 / 1997$ & & + & + \\
\hline АA9/03 & R.S.V. Aurora Australis & CSIRU & 26/11/1997 & + & + & + \\
\hline$\Delta 40706$ & $R S V$ Aurora Australis & & $28 / 02 / 1998$ & + & + & \\
\hline АА9/06 & R.S.V. Aurora Australls & CSIRU/ULg & $31 / 03 / 1998$ & + & + & \\
\hline SS9902 & $R V$ Southern Survevor & CSIRO & 05/02/1999 & + & & \\
\hline 559902 & R.v. southern surveyor & CSIKU & $16 / 02 / 1999$ & + & + & + \\
\hline & & & $16 / 07 / 1999$ & + & + & + \\
\hline AA9901 & R.S.V. Aurora Australis & CSIRU & 05/09/1999 & + & + & + \\
\hline 99R0 & S.V. Astrolabe & ULg & $22 / 10 / 1999$ & + & + & \\
\hline 99R1 & S.V. Astrolabe & ULg & 26/12/1999 & + & + & + \\
\hline OISO10 & R.V. Marion Dufresne & LOCEAN/IPSL & $29 / 01 / 2003$ & & + & \\
\hline AA0301 & R.S.V. Aurora Australis & & $11 / 09 / 2003$ & + & + & \\
\hline & К.ग.v. Аигога Aиstrats & CSIRU/UIg & $29 / 10 / 2003$ & + & + & + \\
\hline
\end{tabular}

air-sea $\mathrm{pCO}_{2}$ gradient. We used the $k$-wind parameterization of Wanninkhof (1992), and the Weiss (1974) formulation of $\alpha$ as a function of sea surface salinity (SSS) and SST. Atmospheric $\mathrm{pCO}_{2}$ data from 1997 were expressed in wet air using the water vapour pressure formulation of Weiss and Price (1980) as a function of SSS and SST.

Data were collocated with bathymetry based on the Smith and Sandwell (1997) global seafloor topography (http:// topex.ucsd.edu/). Data over the CS were gathered and averaged by sorting for depths $<300 \mathrm{~m}$, and data at depths $>1000 \mathrm{~m}$ were considered as open ocean. The sub-Tropical
Front (STF) was identified from gradients of SSS and SST (e.g. Belkin and Gordon, 1996). The STF separates warmer and saltier STZ waters from cooler and fresher SAZ waters.

\section{Results}

3.1 Climatological SST and $\mathrm{pCO}_{2}$ seasonal cycles

Climatological seasonal cycles of SST, $\mathrm{pCO}_{2}$ and $\mathrm{pCO}_{2}$ normalized to a temperature of $14^{\circ} \mathrm{C}\left(\mathrm{pCO}_{2} @ 14^{\circ} \mathrm{C}\right.$, using the algorithms of Copin-Montégut, 1988, 1989) were obtained 
by fitting monthly averages with a wave function in the form of:

$y=a+b \sin \left(\frac{x}{c}+d\right)$

where $y$ is either SST, $\mathrm{pCO}_{2}$ or $\mathrm{pCO}_{2} @ 14^{\circ} \mathrm{C}, x$ is time (julian days) and $a, b, c$, and $d$ are fitted constants.

In the CS, STZ and SAZ, under-saturation of $\mathrm{CO}_{2}$ is observed throughout the year (Figs. 2, 3, 4), showing these regions are perennial sinks for atmospheric $\mathrm{CO}_{2}$. In the 3 regions, similar climatological $\mathrm{pCO}_{2}$ and $\mathrm{pCO}_{2} @ 14^{\circ} \mathrm{C}$ seasonal patterns are observed in timing and amplitude: values decrease from late September to late February (austral spring-summer) as net biological uptake removes dissolved inorganic carbon (DIC) from surface waters. From March to September (austral fall-winter), $\mathrm{pCO}_{2}$ and $\mathrm{pCO}_{2} @ 14^{\circ} \mathrm{C}$ values increase in relation to destratification and mixing of surface waters with DIC rich deeper waters (Goyet et al., 1991; Poisson et al., 1993; Metzl et al., 1991, 1995, 1998, 1999). The amplitude of the seasonal cycle of $\mathrm{pCO}_{2}$ is lower than the one of $\mathrm{pCO}_{2} @ 14^{\circ} \mathrm{C}$ because warming of surface waters during spring and summer leads to a thermodynamic increase of $\mathrm{pCO}_{2}$, that opposes a decrease due to net biological carbon uptake. The thermodynamic effect of SST change on the seasonal amplitude of $\mathrm{pCO}_{2}$ is similar in the CS (51 $\left.\mu \mathrm{atm}\right)$, the STZ (50 $\mu \mathrm{atm})$, and the SAZ (47 $\mu \mathrm{atm})$, because SST amplitude is similar in the 3 regions $\left(3.7^{\circ} \mathrm{C}, 3.6^{\circ} \mathrm{C}\right.$ and $3.3^{\circ} \mathrm{C}$, respectively).

The SSS values for all three water masses do not show a distinct seasonal signal like SST, which is strongly influenced by seasonal heating and cooling of surface waters. The water mass on the Tasmanian CS is a mixture of STZ and SAZ waters (Harris et al., 1987, 1991). This is apparent in our data-set, as the average SSS value in the CS (35.02 \pm 0.17$)$ lies between those of the STZ $(35.19 \pm 0.15)$ and the SAZ (34.73 \pm 0.15$)$. The SSS values in the CS show more scatter than in the other two regions (Figs. 2, 3, 4), suggesting a variable degree of mixing between the STZ and SAZ water masses. For a two end-member mixing model, the water mass on the CS is on average composed of $64 \%$ STZ water, consistent with the annual average of SST in the $\mathrm{CS}\left(13.8 \pm 1.3^{\circ} \mathrm{C}\right)$ being similar to the $\operatorname{STZ}\left(13.4 \pm 1.3^{\circ} \mathrm{C}\right)$ and distinctly different from the SAZ $\left(11.5 \pm 1.2^{\circ} \mathrm{C}\right)$ annual averages.

\subsection{Inter-annual SST and $\mathrm{pCO}_{2}$ variations}

In order to deseasonalize the data-sets and investigate interannual variability, monthly anomalies of SST, $\mathrm{pCO}_{2}$, and $\mathrm{pCO}_{2} @ 14^{\circ} \mathrm{C}$ were computed as the difference between observations and averaged monthly values for all the cruise data. SST anomalies as intense as $2^{\circ} \mathrm{C}$ are observed in the CS, STZ and SAZ (Figs. 2, 3, 4). SST values that are below the climatology tend to coincide with less saline waters suggesting a greater contribution of SAZ waters. Warm anomalies are typically associated with saltier waters implying a cs
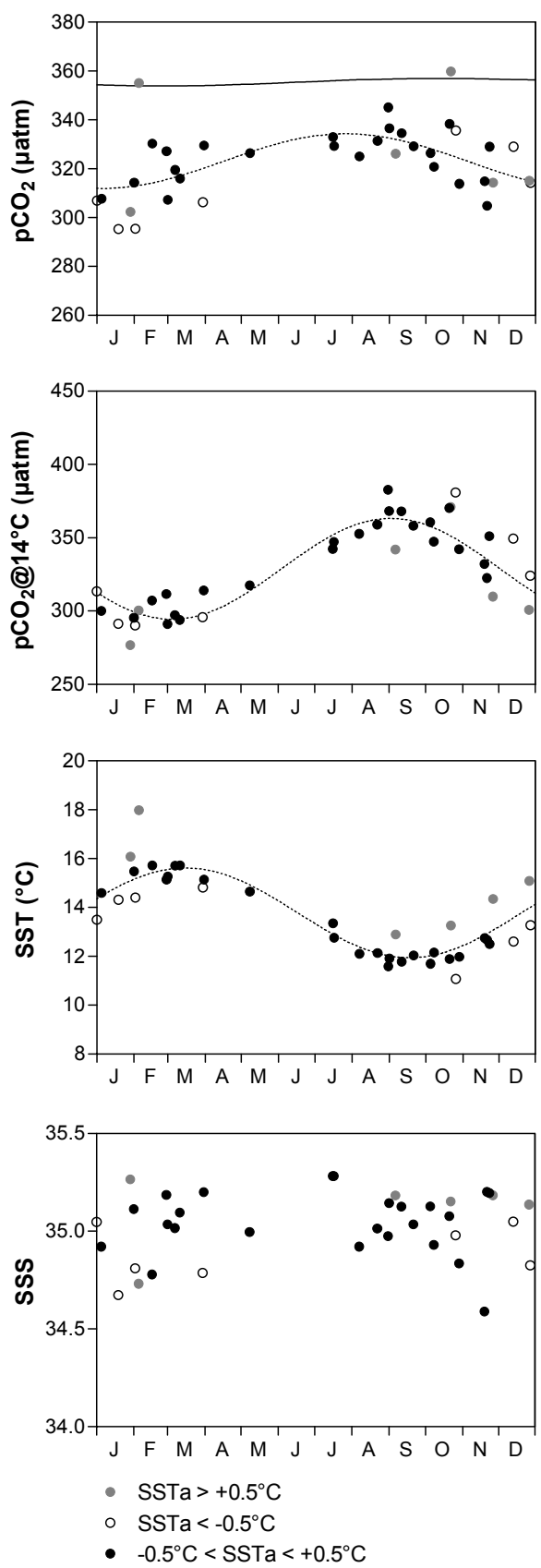

Fig. 2. Seasonal cycles of the partial pressure of $\mathrm{CO}_{2}\left(\mathrm{pCO}_{2}\right)$, the $\mathrm{pCO}_{2}$ normalized to a temperature of $14^{\circ} \mathrm{C}\left(\mathrm{pCO}_{2} @ 14^{\circ} \mathrm{C}\right)$, sea surface temperature (SST) and sea surface salinity (SSS) over the continental shelf (CS) south of Tasmania. Solid line shows atmospheric $\mathrm{pCO}_{2}$ for 1997. Dotted lines show the climatological cycles based on a wave function curve fitted to the monthly averages. Data were sorted for significant positive SST anomalies $\left(\mathrm{SSTa}>0.5^{\circ} \mathrm{C}\right.$, grey circles), significant negative SST anomalies $\left(\mathrm{SSTa}<-0.5^{\circ} \mathrm{C}\right.$, open circles), and no significant SST anomalies $\left(-0.5^{\circ} \mathrm{C}<\mathrm{SSTa}<0.5^{\circ} \mathrm{C}\right.$, black circles). 
STZ
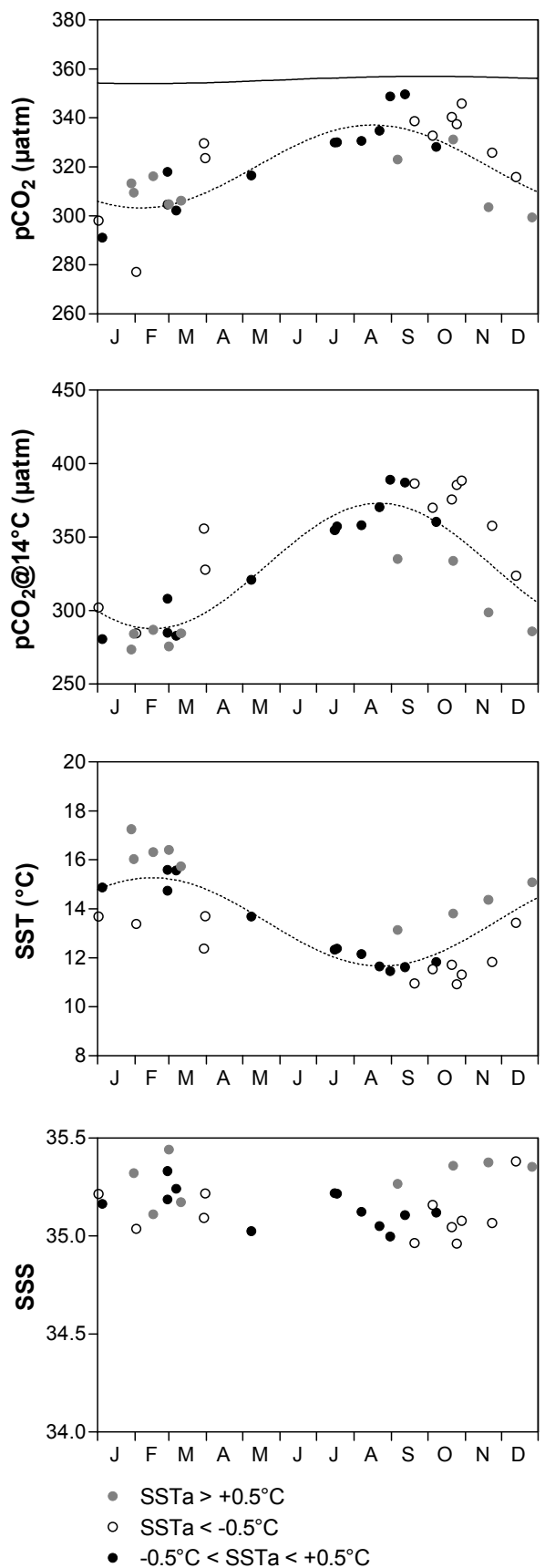

Fig. 3. Seasonal cycles of the partial pressure of $\mathrm{CO}_{2}\left(\mathrm{pCO}_{2}\right)$, the $\mathrm{pCO}_{2}$ normalized to a temperature of $14^{\circ} \mathrm{C}\left(\mathrm{pCO}_{2} @ 14^{\circ} \mathrm{C}\right)$, sea surface temperature (SST) and sea surface salinity (SSS) in the subtropical zone (STZ) south of Tasmania. Solid line shows atmospheric $\mathrm{pCO}_{2}$ for 1997. Dotted lines show the climatological cycles based on a wave function curve fitted to the monthly averages. Data were sorted for significant positive SST anomalies ( $\mathrm{SSTa}>0.5^{\circ} \mathrm{C}$, grey circles), significant negative SST anomalies $\left(\mathrm{SSTa}<-0.5^{\circ} \mathrm{C}\right.$, open circles), and no significant SST anomalies $\left(-0.5^{\circ} \mathrm{C}<\mathrm{SSTa}<0.5^{\circ} \mathrm{C}\right.$, black circles $)$.
SAZ
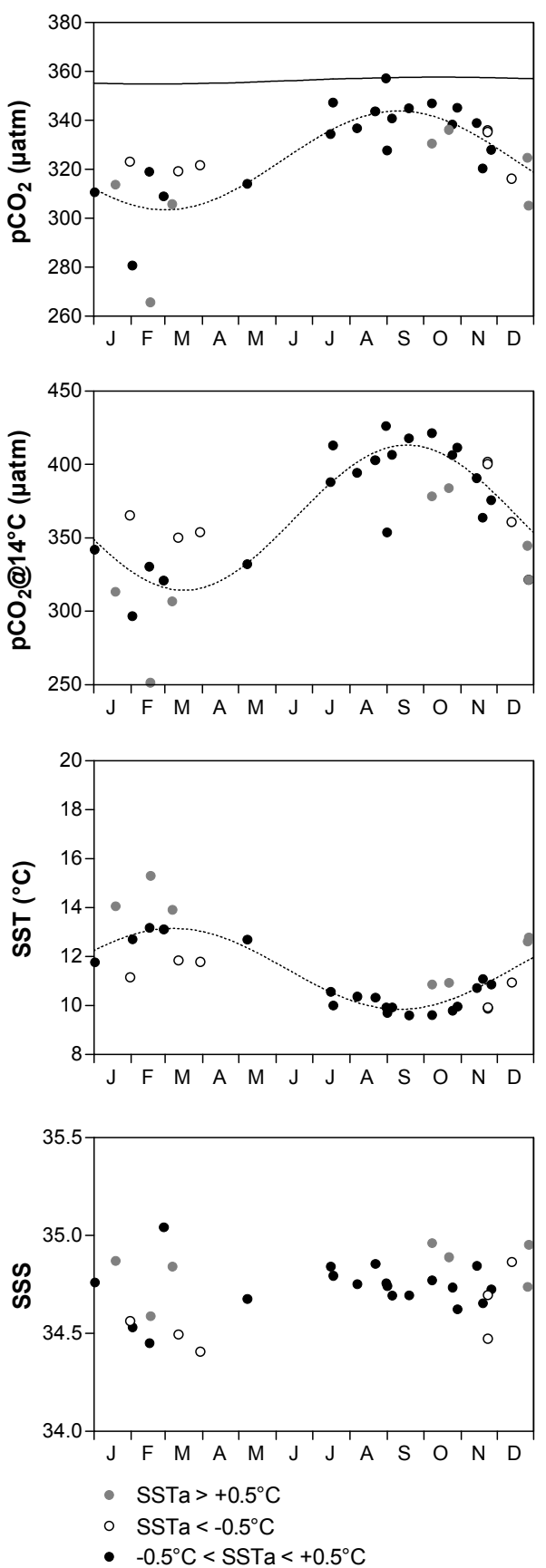

Fig. 4. Seasonal cycles of the partial pressure of $\mathrm{CO}_{2}\left(\mathrm{pCO}_{2}\right)$, the $\mathrm{pCO}_{2}$ normalized to a temperature of $14^{\circ} \mathrm{C}\left(\mathrm{pCO}_{2} @ 14^{\circ} \mathrm{C}\right)$, sea surface temperature (SST) and sea surface salinity (SSS) in the subAntarctic zone (SAZ) south of Tasmania. Solid line shows atmospheric $\mathrm{pCO}_{2}$ for 1997. Dotted lines show the climatological cycles based on a wave function curve fitted to the monthly averages. Data were sorted for significant positive SST anomalies (SSTa $>0.5^{\circ} \mathrm{C}$, grey circles), significant negative SST anomalies (SSTa $<-0.5^{\circ} \mathrm{C}$, open circles), and no significant SST anomalies $\left(-0.5^{\circ} \mathrm{C}<\mathrm{SSTa}<0.5^{\circ} \mathrm{C}\right.$, black circles $)$. 
greater contribution of subtropical waters and consistent with observations of increases in warming and salinity for the region (Rintoul and Sokolov, 2001; Rintoul and Trull, 2001; Morrow et al., 2007).

A comparison of the monthly SST anomalies with anomalies for $\mathrm{pCO}_{2}$ and $\mathrm{pCO}_{2} @ 14^{\circ} \mathrm{C}$ show consistent patterns in the three regions (Figs. 2, 3, 4). Values of $\mathrm{pCO}_{2} @ 14^{\circ} \mathrm{C}$ associated with positive SST anomalies $\left(>0.5^{\circ} \mathrm{C}\right)$ generally lie below the climatological $\mathrm{pCO}_{2} @ 14^{\circ} \mathrm{C}$ cycle. Values associated with significant negative SST anomalies $\left(<-0.5^{\circ} \mathrm{C}\right)$ generally lie above the climatological $\mathrm{pCO}_{2} @ 14^{\circ} \mathrm{C}$ cycle. The patterns for $\mathrm{pCO}_{2}$ anomalies are not as clear. In the STZ, positive $\mathrm{pCO}_{2}$ and $\mathrm{pCO}_{2} @ 14^{\circ} \mathrm{C}$ anomalies correspond to negative SST anomalies during spring (OctoberDecember). However, during the summer (January-March) the $\mathrm{pCO}_{2}$ anomalies in the STZ show the opposite behavior of $\mathrm{pCO}_{2} @ 14^{\circ} \mathrm{C}$. For summer, the $\mathrm{pCO}_{2}$ values associated with positive SST anomalies generally occur above the climatological $\mathrm{pCO}_{2}$ cycle, and values associated with significant negative SST anomalies tend to lie below the climatological $\mathrm{pCO}_{2}$ cycle.

In the 3 regions, $\mathrm{pCO}_{2} @ 14^{\circ} \mathrm{C}$ anomalies are well correlated with SST anomalies, with different slopes for the spring-summer and fall-winter periods (Fig. 5). The $\mathrm{pCO}_{2}$ anomalies in the 3 regions show more scatter than $\mathrm{pCO}_{2} @ 14^{\circ} \mathrm{C}$ anomalies versus SST anomalies (Fig. 5). This is due to the thermodynamic effect of temperature change that leads to a decrease of the positive $\mathrm{pCO}_{2}$ anomalies associated with negative SST anomalies, and conversely to an increase of negative $\mathrm{pCO}_{2}$ anomalies associated with positive SST anomalies. In some extreme cases there is a reversal of the direction of the $\mathrm{pCO}_{2}$ anomalies, particularly in the STZ (Fig. 5).

The SST anomalies in the STZ, SAZ and CS are roughly consistent in timing and amplitude (Fig. 6), suggesting a similar driver of these anomalies in the three water masses. Large-scale coupled atmosphere-ocean oscillations likely to drive large SST anomalies in the mid-latitude band of the Southern Ocean are ENSO through atmospheric bridges $(\mathrm{Li}$, 2000; Verdy et al., 2006; Morrow et al., 2007), the subtropical dipole pattern (Behera and Yamagata, 2001), or SAM (Hall and Visbeck, 2002; Lovenduski and Gruber, 2005; Morrow et al., 2007).

The patterns of inter-annual variability of SST and wind speed $\left(u_{10}\right)$ were investigated south of Tasmania using timeseries including years 1982 to 2005 from the Reynolds et al. (2002) monthly SST climatology (Reyn_SmithOIv2, http://iridl.ldeo.columbia.edu/) and the Kalnay et al. (1996) National Centers for Environmental Prediction (NCEP) Reanalysis-1 daily $u_{10}$ (http://www.cdc.noaa.gov/). Deseasonalized SST and $u_{10}$ reveal strong inter-annual variability for the 1982-2005 period, with low wind speed associated to higher SST (Fig. 7). Such patterns have been previously reported at mid-latitudes of the Southern Ocean in conjunction with changes in SAM (Hall and Visbeck, 2002; Lovenduski and Gruber, 2005; Morrow et al., 2007). Figure 7 shows that low wind speed years are in general associated with positive phases of SAM, although not as clear during the 19931998 period, possibly related to ENSO and SAM interactions (Verdy et al., 2006, 2007).

\subsection{Inter-annual air-sea $\mathrm{CO}_{2}$ flux variations}

In order to examine the relationship of SST anomalies to inter-annual variations of air-sea $\mathrm{CO}_{2}$ fluxes, we lengthen the oceanic $\mathrm{pCO}_{2}$ time-series to include the years 1982 to 2005 using SST time-series and our previously established relationships between observed SST and $\mathrm{pCO}_{2} @ 14^{\circ} \mathrm{C}$ from 1991-2003. Wind speed data from the two NCEP grid nodes in the study region (Fig. 1) were averaged and assumed representative of $u_{10}$ over the CS, STZ and SAZ. The Reyn_SmithOIv2 SST grid node $n^{\circ} 1$ (Fig. 1) was used to compute monthly SST anomalies for the CS. The remaining SST grid nodes $\left(\mathrm{n}^{\circ} 2\right.$ to $\mathrm{n}^{\circ} 11$, Fig. 1$)$ were averaged, and used to compute monthly SST anomalies for the STZ and SAZ. This assumes that SST anomalies in the STZ and SAZ are synchronous and similar in amplitude and direction as shown in Fig. 6. Also, the position of the STF is highly variable in time (Sokolov and Rintoul, 2002) and it is not possible to arbitrarily associate the SST grid nodes to either STZ or SAZ water masses.

The $\mathrm{pCO}_{2} @ 14^{\circ} \mathrm{C}$ anomalies were computed from the Reyn_SmithOIv2 monthly SST anomalies using the linear relationships shown in Fig. 5. These $\mathrm{pCO}_{2} @ 14^{\circ} \mathrm{C}$ anomalies were added to the climatological $\mathrm{pCO}_{2} @ 14^{\circ} \mathrm{C}$ cycles shown in Figs. 2, 3 and 4. The Reyn_SmithOIv2 monthly SST anomalies were added to the climatological SST cycles shown in Figs. 2, 3 and 4 . The $\mathrm{pCO}_{2}$ values were then computed from $\mathrm{pCO}_{2} @ 14^{\circ} \mathrm{C}$ and SST (both including the respective anomalies), using the algorithms of CopinMontégut $(1988,1989)$. The daily air-sea $\mathrm{CO}_{2}$ fluxes were calculated using Eq. (2), and the NCEP $u_{10}$ data.

For the whole 1982-2005 period, the CS, STZ and SAZ act annually as sinks for atmospheric $\mathrm{CO}_{2}$ at the rate of, respectively, $-6.4 \pm 0.7,-6.8 \pm 0.5$, and $-5.7 \pm 0.5 \mathrm{mmol} \mathrm{C} \mathrm{m}^{-2} \mathrm{~d}^{-1}$. Significant potential interannual variability of annual $F$ is apparent in the 3 regions (Figs. 7, 8). Consistent with $\mathrm{pCO}_{2}$, negative annual $F$ anomalies (stronger sink for atmospheric $\mathrm{CO}_{2}$ ) are associated with positive annual SST anomalies, and conversely positive annual $F$ anomalies (weaker sink for atmospheric $\mathrm{CO}_{2}$ ) are associated with negative annual SST anomalies for the 3 regions. For positive annual SST anomalies, the strongest $F$ anomalies (Table 2) lead to an increase of the 1982-2005 average annual sink for atmospheric $\mathrm{CO}_{2}$ of 26, 21 , and $59 \%$, in the CS, STZ and SAZ, respectively. For negative annual SST anomalies, the strongest $F$ anomalies (Table 2) lead to a decrease of the 1982-2005 average annual sink for atmospheric $\mathrm{CO}_{2}$ of 15,11 , and $51 \%$, in the CS, STZ and SAZ, respectively. For positive annual SST anomalies, 
CS

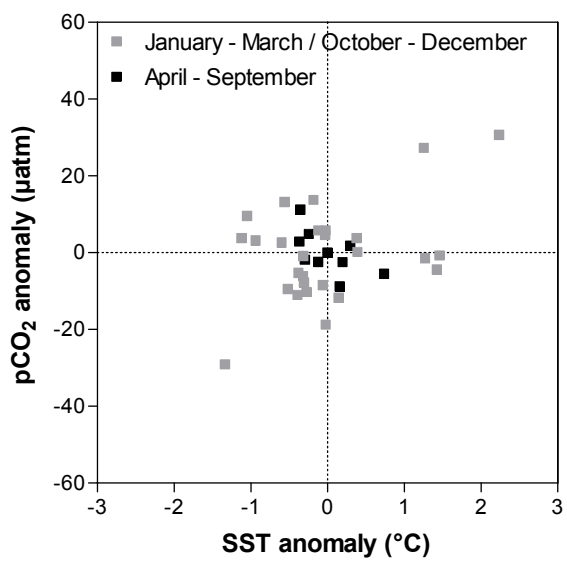

STZ

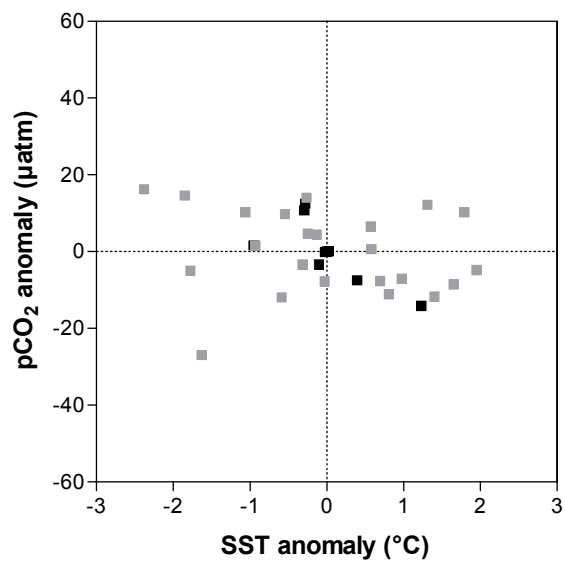

SAZ

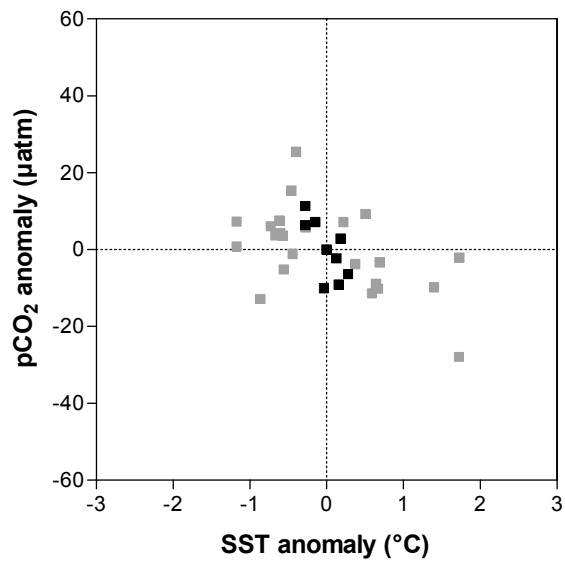

CS

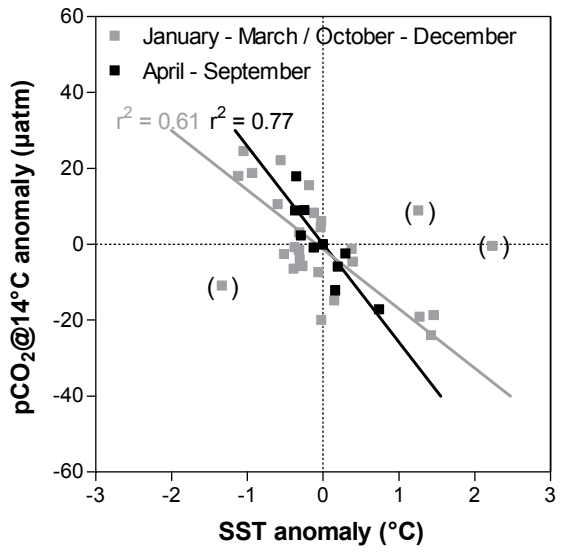

STZ

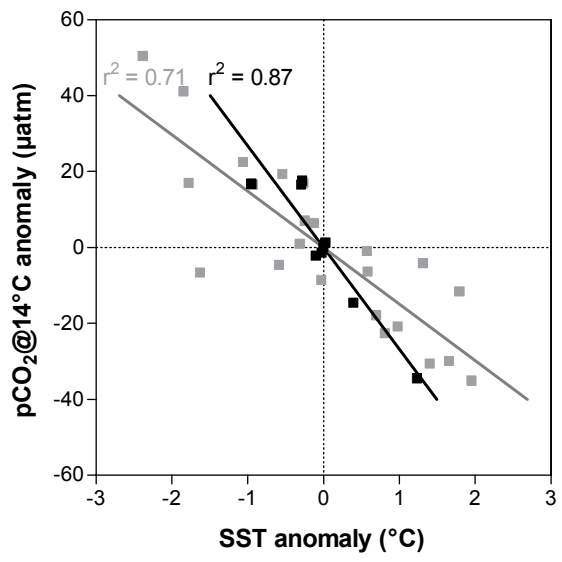

SAZ

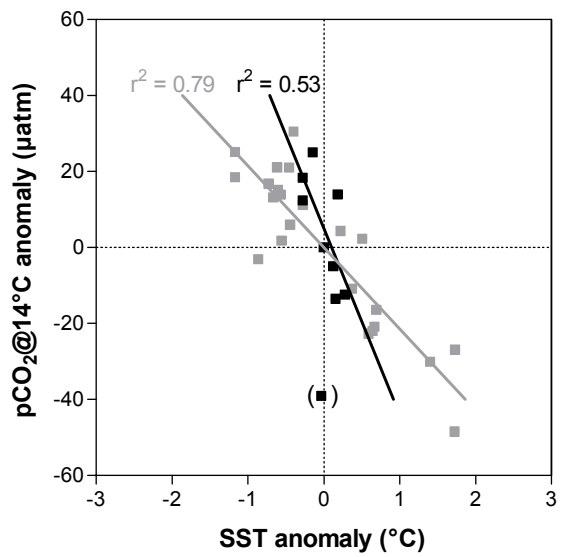

Fig. 5. Monthly anomalies of the partial pressure of $\mathrm{CO}_{2}\left(\mathrm{pCO}_{2}\right)$ and of the $\mathrm{pCO}_{2}$ normalized to a temperature of $14^{\circ} \mathrm{C}\left(\mathrm{pCO} 2 @ 14^{\circ} \mathrm{C}\right)$ plotted against the sea surface temperature (SST) monthly anomalies in the continental shelf (CS), the subtropical zone (STZ) and subAntarctic zone (SAZ) south of Tasmania, for the spring-summer period (grey squares) and the fall-winter period (black squares). Solid lines correspond to linear regression functions, and $r^{2}$ to the corresponding coefficient of determination (winter-fall in black, spring-summer in grey). Symbols in brackets were excluded from the linear regressions. 


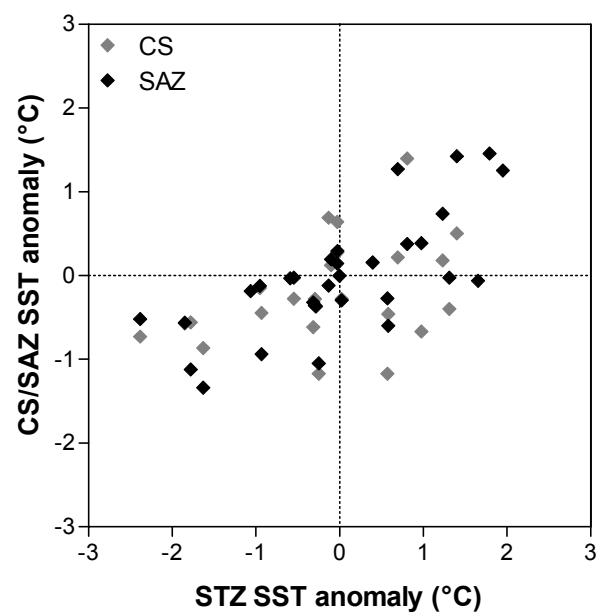

Fig. 6. Sea surface temperature (SST) monthly anomalies in the continental shelf (CS) and subAntarctic zone (SAZ) plotted against the SST monthly anomalies in the subtropical zone (STZ), south of Tasmania.

the average $F$ anomalies (Table 2) cause an increase of the 1982-2005 average annual sink for atmospheric $\mathrm{CO}_{2}$ of 5, 3, and $21 \%$, in the CS, STZ and SAZ, respectively. For negative annual SST anomalies, the average $F$ anomalies (Table 2) lead to a decrease of the 1982-2005 average annual sink for atmospheric $\mathrm{CO}_{2}$ of 4,3 , and $18 \%$, for the CS, STZ and $\mathrm{SAZ}$, respectively.

The annual $F$ anomalies computed from the 1982-2005 mean of daily $u_{10}$ data show a consistent negative relationship with the annual SST anomalies for all three regions (Fig. 8). This suggests the scatter in the annual $F$ anomalies computed from daily $u_{10}$ data versus the annual SST anomalies is to a large extent related to inter-annual variability in $u_{10}$. In particular, the annual $F$ anomalies in 1985, 1989, 1999 and 2001 are smaller compared to other years for the 3 regions, leading to positive annual $F$ anomalies in the CS and the STZ during 1985, 1989 and 1999, and to virtually neutral annual $F$ anomalies in the SAZ during 1985 and 1989.

The $F$ anomalies computed for the fall-winter and springsummer periods using the 1982-2005 mean of daily $u_{10}$ (Fig. 9) show that the annual $F$ anomalies (Fig. 8) are mainly driven by the fluxes during the fall-winter period. This is related to the thermodynamic effect of temperature change that tends to reduce the magnitude of $\mathrm{pCO}_{2}$ anomalies, and due to SST anomalies being more marked during the periods of stratification (spring-summer, Figs. 2, 3, 4). Higher wind speeds during the fall-winter period (not shown) are also responsible for the larger contribution of $F$ anomalies during this period. These patterns are reflected in the $F$ anomalies computed for the fall-winter and spring-summer periods using the daily $u_{10}$, but with more scatter due to inter-annual variability of $u_{10}$ (Fig. 9). The small annual $F$ anomalies in 1985, 1989, 1999 and 2001 (Fig. 8) are due to the spring-
Table 2. The strongest and average annual anomalies of air-sea $\mathrm{CO}_{2}$ fluxes $(F)$ for positive and negative sea surface temperature (SST) annual anomalies in the continental shelf (CS), the subtropical zone (STZ) and subAntarctic zone (SAZ) south of Tasmania, from 1982 to 2005 . Annual anomalies were computed as the difference between the annual mean value and the average of annual mean values of the whole data-set.

\begin{tabular}{lccc}
\hline & $\mathrm{CS}$ & $\mathrm{STZ}$ & $\mathrm{SAZ}$ \\
\hline Strongest annual $F$ anomaly $\left(\mathrm{mmol} \mathrm{C} \mathrm{m}^{-2}\right.$ & $\left.\mathrm{d}^{-1}\right)$ \\
\hline Positive SST anomalies & -1.7 & -1.4 & -3.4 \\
Negative SST anomalies & 1.0 & 0.8 & 2.9 \\
\hline Average annual $F$ anomaly $\left(\mathrm{mmol} \mathrm{C} \mathrm{m}^{-2} \mathrm{~d}^{-1}\right)$ \\
\hline Positive SST anomalies & -0.3 & -0.2 & -1.2 \\
Negative SST anomalies & 0.3 & 0.2 & 1.0 \\
\hline
\end{tabular}

summer $F$ anomalies (Fig. 9). Figure 7 shows that $u_{10}$ in 1985, 1989, 1999 and 2001 was lower than other years. This is most likely related to a poleward shift of westerly winds related to changes in the SAM which causes a local decrease in wind stress and positive SST anomalies (Hartmann and Lo, 1998) and reduced air-sea fluxes of $\mathrm{CO}_{2}$ (Fig. 7).

\section{Discussion}

\subsection{Causes of the observed inter-annual variability of $\mathrm{pCO}_{2}$ and SST}

SAM, which is characterized by changes in atmospheric mass between $20^{\circ} \mathrm{S}$ and $90^{\circ} \mathrm{S}$ is the principal mode of atmospheric forcing and climate variability in the Southern Ocean. SAM induces changes in the strength of westerly winds which induce significant changes in ocean circulation with potential to significantly impact on biogeochemical carbon cycling and air-sea $\mathrm{CO}_{2}$ fluxes (Le Quéré et al., 2007; Lenton and Matear, 2007; Lovenduski et al., 2007; Verdy et al., 2007). A change in the SAM index leads to synchronous SST anomalies in the STZ and SAZ (Lovenduski and Gruber, 2005; Lovenduski et al., 2007), as observed in our dataset (Figs. 6, 7). An increase in the SAM index is associated with a poleward shift of westerly winds with a local decrease in wind stress (Fig. 7; Hartmann and Lo, 1998; Thompson and Wallace, 2000). This causes an increase in Ekman convergence in the SAZ, with deepening isopycnals, surface warming in the mid-latitudes, and a southward expansion of subtropical waters (Cai et al., 2005; Roemmich et al., 2007). Near Tasmania, surface warming and an increased outflow of warm and salty subtropical waters from the South Tasman Sea have been observed and linked to a polewards shift in the wind stress over the Southern Ocean (Rintoul and Sokolov, 

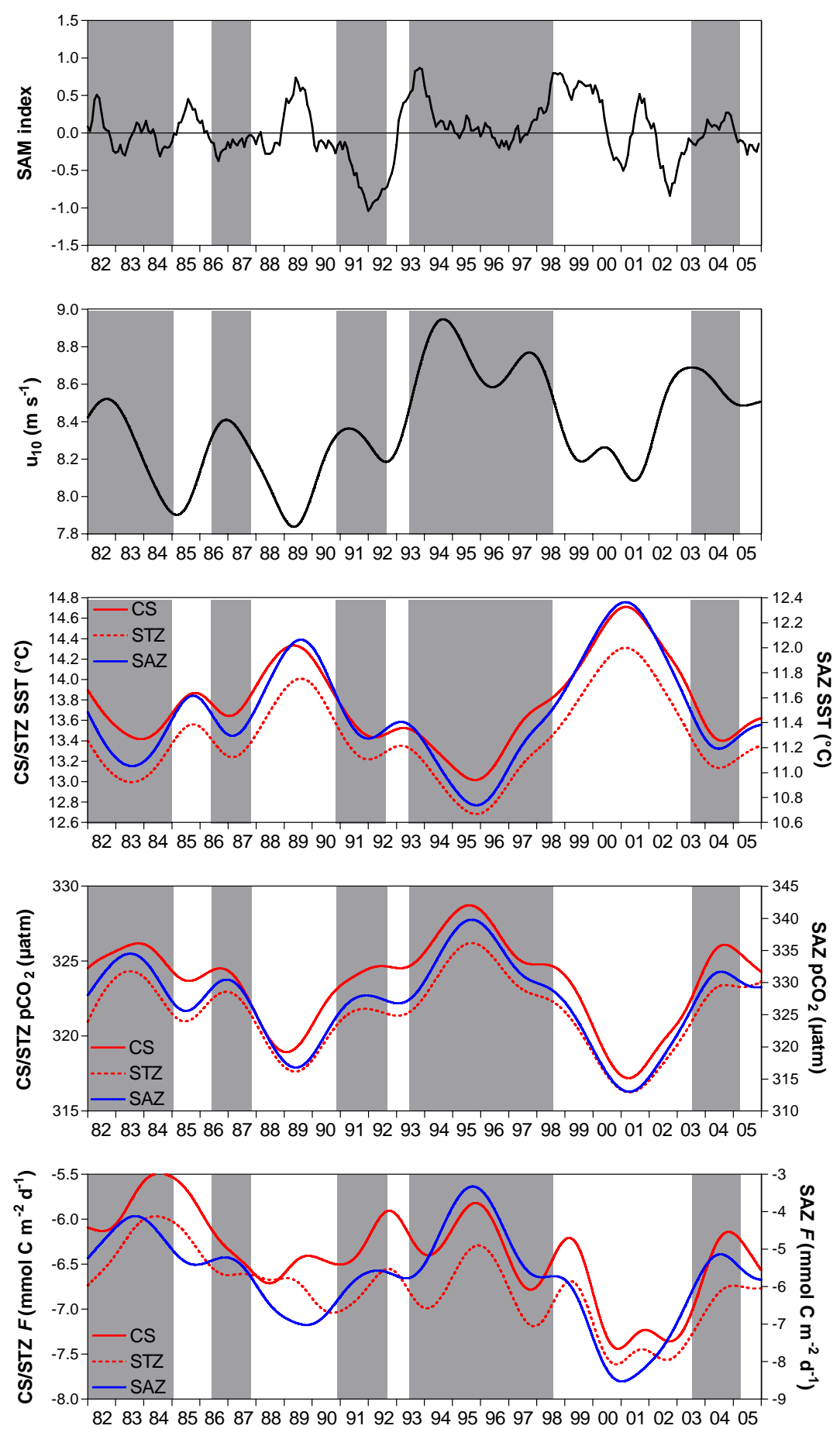

Fig. 7. Time-series from 1982 to 2005 of southern annular mode (SAM) index and of deseasonalized wind speed $\left(u_{10}\right)$, sea surface temperature (SST), partial pressure of $\mathrm{CO}_{2}\left(\mathrm{pCO}_{2}\right)$ and air-sea $\mathrm{CO}_{2}$ fluxes $(F)$ in the continental shelf $(\mathrm{CS})$, the subtropical zone $(\mathrm{STZ})$ and subAntarctic zone (SAZ) south of Tasmania. Grey areas correspond to periods of sustained negative SST anomalies. Signals were deseasonalized using a Gaussian one year low pass filter. SAM index was obtained from the National Oceanic and Atmospheric Administration Climate Prediction Center (http://www.cpc.ncep.noaa.gov/) and smoothed with a one year running mean. Details on the computations of SST, $\mathrm{pCO}_{2}$ and $F$ for the 3 regions are given in Sect. 3.3. 
Daily $\mathrm{u}_{10}$

cS

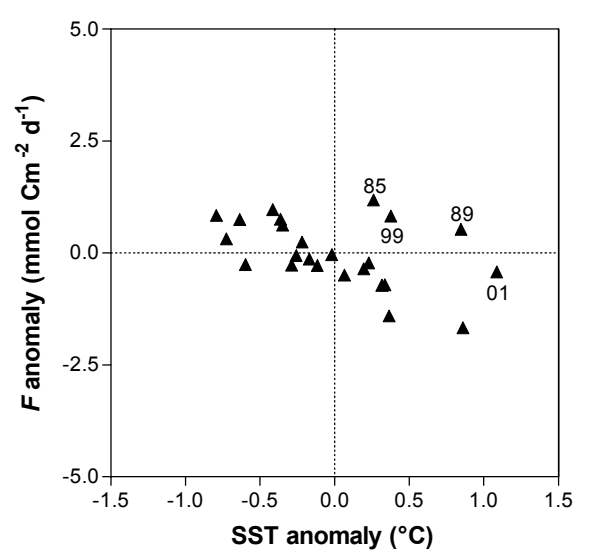

STZ

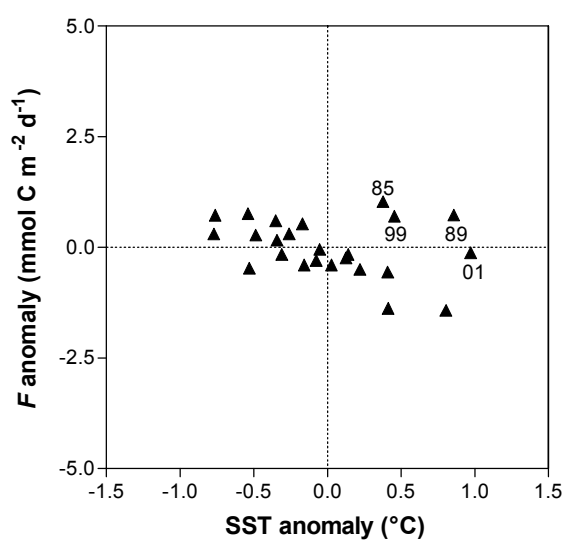

SAZ

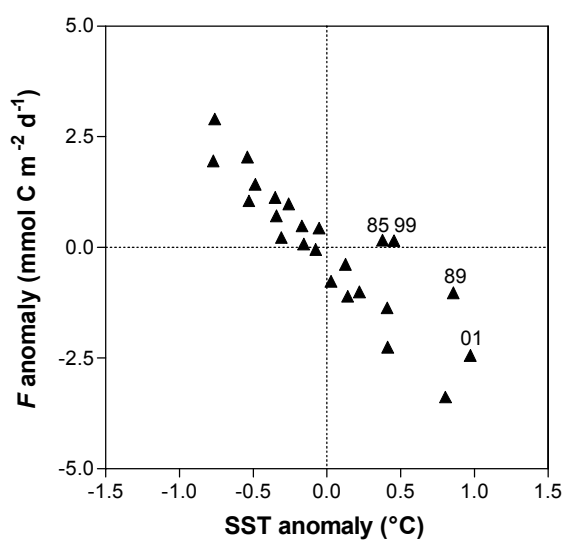

1982-2005 mean of daily $u_{10}$

CS

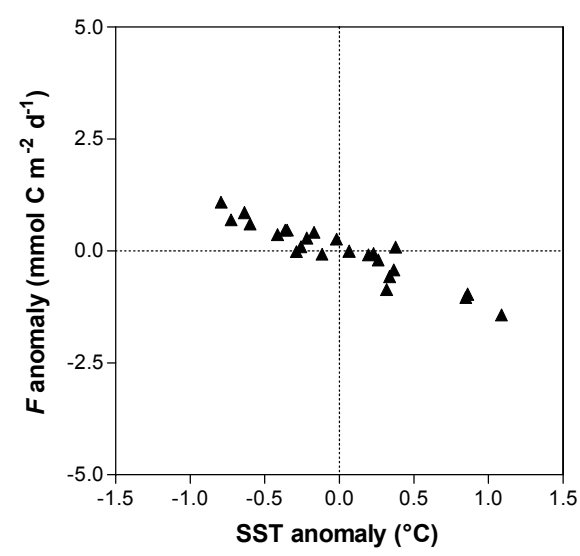

STZ

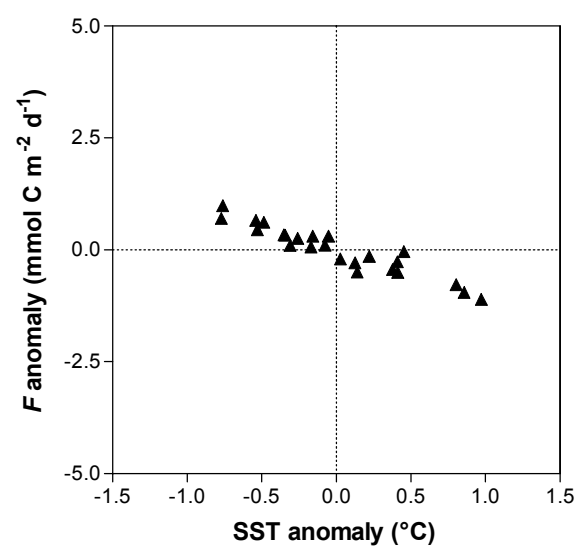

SAZ

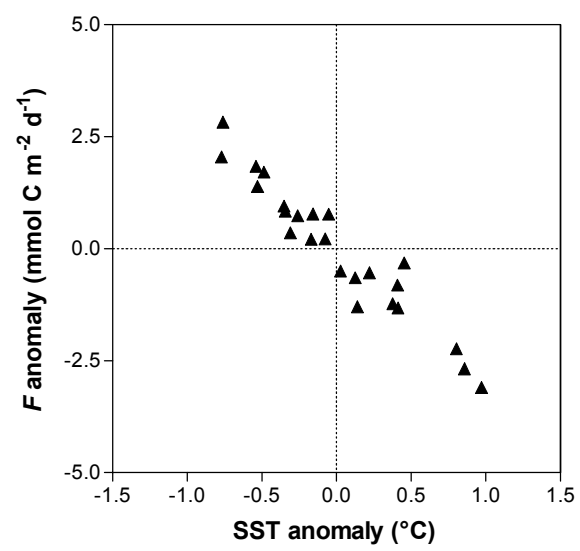

Fig. 8. Annual anomalies of air-sea $\mathrm{CO}_{2}$ fluxes $(F)$ computed with daily wind speeds $\left(u_{10}\right)$ and 1982-2005 mean of daily $u_{10}$, plotted against the sea surface temperature (SST) annual anomalies in the continental shelf (CS), the subtropical zone (STZ) and subAntarctic zone (SAZ) south of Tasmania, from 1982 to 2005. Annual anomalies were computed as the difference between the annual mean value and the average of annual mean values of the whole data-set. 
Daily $\mathbf{u}_{10}$

CS

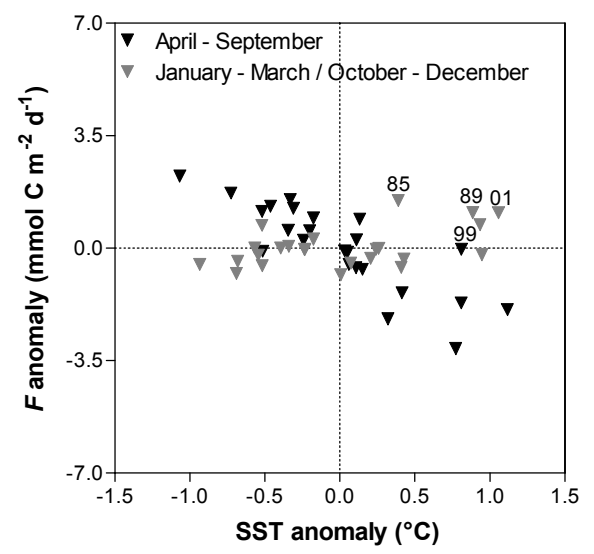

STZ

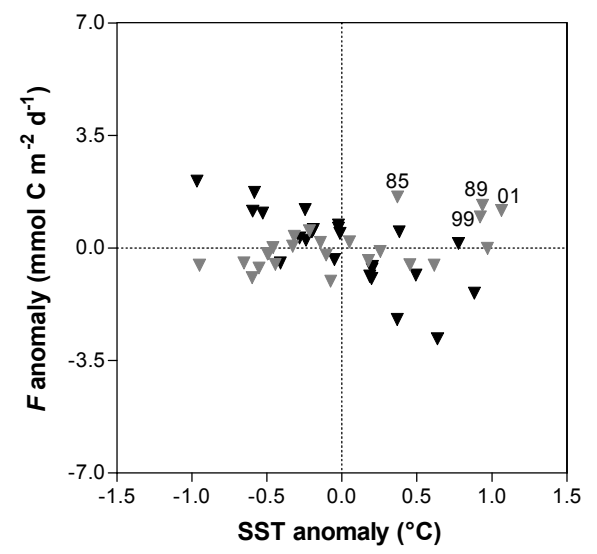

SAZ

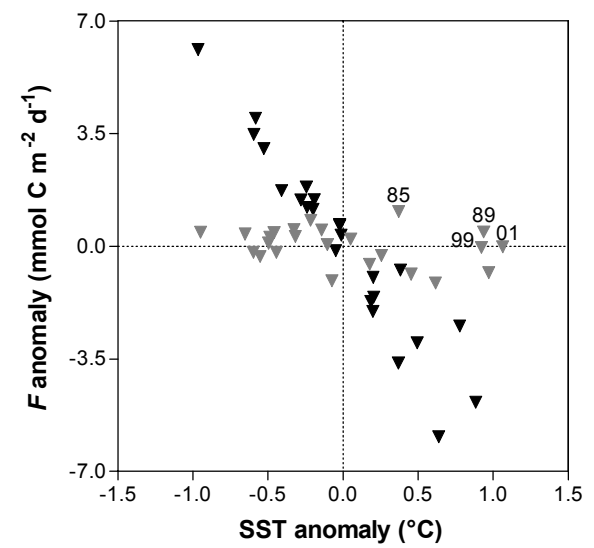

1982-2005 mean of daily $u_{10}$

CS

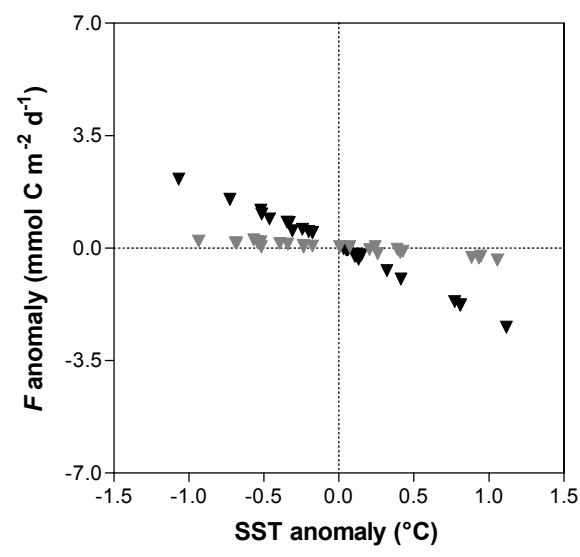

STZ

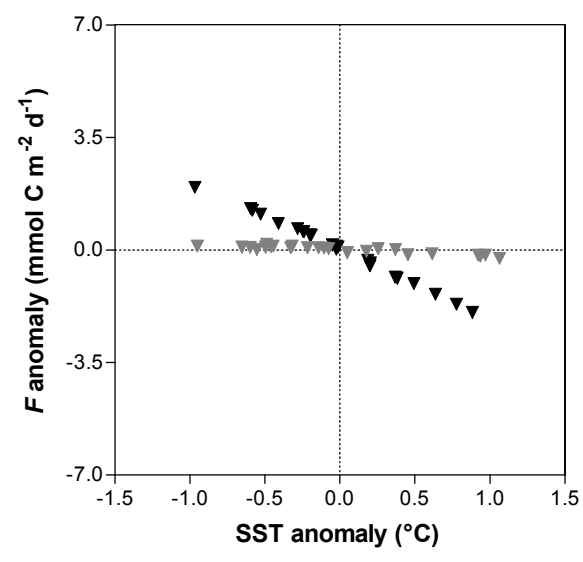

SAZ

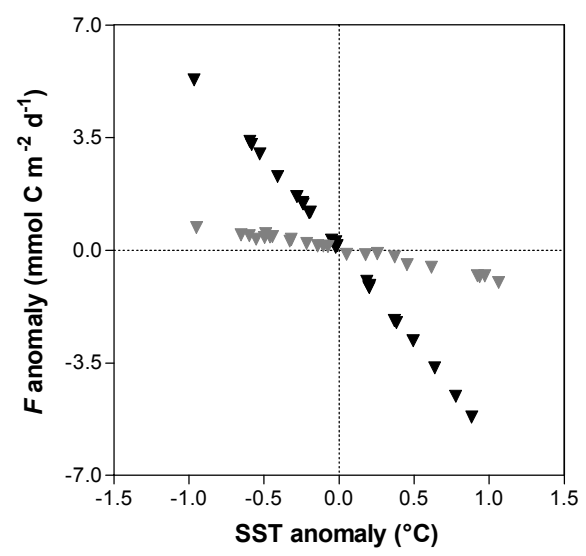

Fig. 9. Anomalies of air-sea $\mathrm{CO}_{2}$ fluxes $(F)$ computed with daily wind speeds $\left(u_{10}\right)$ and 1982-2005 mean of daily $u_{10}$, plotted against the sea surface temperature (SST) anomalies in the continental shelf (CS), the subtropical zone (STZ) and subAntarctic zone (SAZ) south of Tasmania, for the spring-summer period (grey triangles) and the fall-winter period (black triangles), from 1982 to 2005 . Spring-summer (fall-winter) period anomalies were computed as the difference between the spring-summer (fall-winter) period mean value and the average of spring-summer (fall-winter) period mean values of the whole data-set (winter-fall in black, spring-summer in grey). 

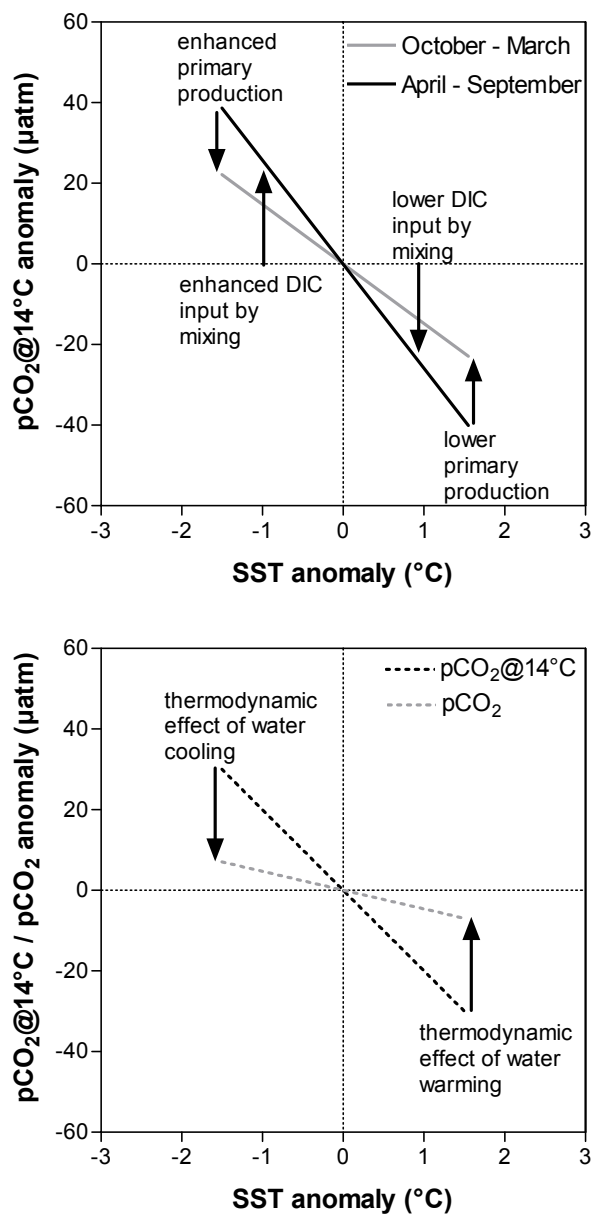

Fig. 10. Conceptual model relating the partial pressure of $\mathrm{CO}_{2}$ $\left(\mathrm{pCO}_{2}\right)$ normalized to a temperature of $14^{\circ} \mathrm{C}\left(\mathrm{pCO}_{2} @ 14^{\circ} \mathrm{C}\right)$, and $\mathrm{pCO}_{2}$ anomalies to sea surface temperature (SST) anomalies south of Tasmania.

2001; Morrow et al., 2007; Ridgway, 2007), in agreement with our inter-annual analysis of SST (Fig. 7).

A reduction in available nutrients and reduced DIC input through either the expansion of subtropical waters or less vertical mixing, could explain the observed relationship between $\mathrm{pCO}_{2} @ 14^{\circ} \mathrm{C}$ and SST anomalies for all 3 regions (Figs. 5, 10). Surface waters of the Tasman Sea have relatively low macronutrient concentrations (Condie and Dunn, 2006) and low $\mathrm{pCO}_{2}$ values (Takahashi et al., 2002), compared to subAntarctic waters to the south of the STF. The surface warming and decreased wind stress associated with a positive SAM index will also produce a deepening of isopycnal surfaces (Roemmich et al., 2007) and result in more stratified surface mixed layers, thus reducing the potential to entrain subsurface waters with high nutrient and DIC concentrations into the surface mixed layer over winter. The net effect of altered vertical mixing and the southerly expansion of the subtropical waters should be to produce warm SST anomalies and low $\mathrm{pCO}_{2} @ 14^{\circ} \mathrm{C}$ values in the mid-latitude waters. Conversely, during periods when the SAM index is reduced, there is likely to be a greater supply of nutrients and DIC to the surface layer through vertical mixing and a retreat of subtropical waters to the north. Under these conditions the surface waters are expected to contain a greater component of relatively high nutrient and DIC waters of the SAZ, producing cool SST anomalies and high $\mathrm{pCO}_{2} @ 14^{\circ} \mathrm{C}$ anomalies (Fig. 10).

Inter-annual variability in physical forcing related to SAM could also explain different slopes between $\mathrm{pCO}_{2} @ 14^{\circ} \mathrm{C}$ anomalies and SST anomalies observed during springsummer and fall-winter periods (Figs. 5, 10). Years with negative SST anomalies would be associated with enhanced nutrient and DIC inputs. Primary production in the region may be partly limited by nutrient availability (Boyd et al., 2001). Years of greater nutrient availability associated with negative SST anomalies would lead to enhanced primary production during spring and summer, and a decrease of the slope (becomes less negative) between $\mathrm{pCO}_{2} @ 14^{\circ} \mathrm{C}$ and SST anomalies for the fall-winter to spring-summer periods (Fig. 10). The overall negative relationship between $\mathrm{pCO}_{2} @ 14^{\circ} \mathrm{C}$ anomalies and SST anomalies (Fig. 5) shows that the enhanced primary production associated with negative SST anomalies does not overcome the enhanced winter inputs of DIC.

4.2 Inter-annual variability indicative of future change and potential feedback on increasing atmospheric $\mathrm{CO}_{2}$ ?

Examining the relationship between anomalies in $F$ and SST on inter-annual time scales provides insights of biogeochemical responses to projected long-term trends in SST and stratification of the Southern Ocean. Based on correlations of remotely sensed chlorophyll-a and SST, Le Quéré et al. (2002) suggested that an increase of SST would lead to an overall increase in primary production in the Southern Ocean. This was attributed to stronger light limitation compared to nutrient limitation for most regions of the Southern Ocean and supported by the simulation of propagating warm anomalies using a biogeochemical ocean general circulation model (Le Quéré et al., 2003). Bopp et al. (2001) have also suggested that export production in the Southern Ocean will increase with projected warming of surface waters. The comparison of $\mathrm{pCO}_{2} @ 14^{\circ} \mathrm{C}$ and SST anomalies during fall-winter and spring-summer periods (Fig. 5) suggests that in our study region an increase of SST leads to a decrease of export production (Fig. 10). This is in agreement with evidence for nutrient rather than of light limitation of primary production for the sub-polar waters near Tasmania (Boyd et al., 2001).

Besides modifying export production, warming of surface waters will also change air-sea $\mathrm{CO}_{2}$ fluxes due to changes of the input of $\mathrm{CO}_{2}$ from deeper layers. Indeed, numerical models of $\mathrm{CO}_{2}$ dynamics and air-sea $\mathrm{CO}_{2}$ exchange in the Southern Ocean highlight the very significant role of vertical mixing at seasonal (Louanchi et al., 1996; Metzl et al., 
1999, 2006) and inter-annual (Louanchi and Hoppema, 2000; Verdy et al., 2007) time scales. Changes in vertical mixing in the Southern Ocean can have an impact on the intensity of the air-sea $\mathrm{CO}_{2}$ fluxes and can potentially modulate the atmospheric $\mathrm{CO}_{2}$ content by changing the natural biogeochemical $\mathrm{CO}_{2}$ cycle (Matear and Hirst, 1999). Indeed, to explain the decrease of atmospheric $\mathrm{CO}_{2}$ during the last glacial period, some hypotheses are based on a decrease in the ventilation of deep DIC rich water in relation to an increase of stratification (Toggweiler, 1999; Sigman and Boyle, 2000), due to a northward shift of the westerly winds (Toggweiler et al., 2006) or due to an increase of salinity in deeper waters (Watson and Naveira Garabato, 2006). The decrease of vertical inputs of DIC at high latitudes combined with constant or enhanced export production could have increased the biological pump (in regions of light limitation for primary production) and enhanced the atmospheric $\mathrm{CO}_{2}$ sink (Toggweiler, 1999; Sigman and Boyle, 2000; Toggweiler et al., 2006; Watson and Naveira Garabato, 2006). This clearly illustrates that a modification of the natural biogeochemical cycle of $\mathrm{CO}_{2}$ in the Southern Ocean can lead to strong feedbacks on the atmospheric $\mathrm{CO}_{2}$ content.

Our study region is small but includes a portion of two important waters masses: the STZ and SAZ. Our data-based inter-annual variability analysis does indicate that a decrease of vertical input of DIC during winter due to positive SST anomalies could lead to an increase of the sink for atmospheric $\mathrm{CO}_{2}$. This suggests that warming of surface waters of some regions of the Southern Ocean, may lead to a negative feedback on increasing atmospheric $\mathrm{CO}_{2}$.

\section{Conclusions}

We compiled data obtained along 40 transects during 22 cruises carried out between 1991 and 2003, on the CS and adjacent open oceanic waters south of Tasmania. This allowed us to analyze inter-annual variations of $\mathrm{pCO}_{2}$ and airsea $\mathrm{CO}_{2}$ exchange and examine how they vary in relation to warm and cool anomalies. Strong SST anomalies up to $2^{\circ} \mathrm{C}$ were observed in the STZ and the SAZ. As the waters on the CS are a mixture of STZ and SAZ, these SST anomalies also propagate onto the CS. The consistency in timing and amplitude of SST anomalies in the STZ and SAZ can only be attributed to a large scale coupled atmosphere-ocean oscillation.

Overall, positive SST anomalies are associated with negative $\mathrm{pCO}_{2} @ 14^{\circ} \mathrm{C}$ anomalies, and negative SST anomalies with positive $\mathrm{pCO}_{2} @ 14^{\circ} \mathrm{C}$ anomalies, in the $\mathrm{CS}, \mathrm{STZ}$ and SAZ. This seems to be related to a reduced input of DIC during the fall-winter period, during the phases of positive SST anomalies, in relation to a poleward shift of the westerly winds, and a local decrease in wind stress.

The potential effect of SST anomalies on air-sea $\mathrm{CO}_{2} \mathrm{ex}-$ change were investigated using a 23 years consistent time- series of SST and wind speed. The general pattern is an increase in the sink for atmospheric $\mathrm{CO}_{2}$ associated with positive SST anomalies, mainly during the fall-winter period. However, this general pattern is strongly modulated by interannual variations of wind speed that affects the gas transfer velocity and the intensity of the air-sea $\mathrm{CO}_{2}$ flux.

Assuming that phases of positive SST anomalies are indicative of the future evolution of ocean biogeochemistry under global warming, we show based on a spatially restricted observational data-set, that some provinces of the Southern Ocean could provide a potential negative feedback on increasing atmospheric $\mathrm{CO}_{2}$ and associated climate change. The observations from our region are in agreement with recent modelling studies that show during positive phases of SAM a decrease of the $\mathrm{CO}_{2}$ sink in high latitude areas of the Southern Ocean due to enhanced upwelling and an increase of the $\mathrm{CO}_{2}$ sink in the low latitude areas of the Southern Ocean (Le Quéré et al., 2007; Lenton and Matear, 2007; Lovenduski et al., 2007). It is clear that larger scale investigation in the Southern Ocean is required to quantify more rigorously potential feedbacks on the increase of atmospheric $\mathrm{CO}_{2}$ due to SST changes in surface waters.

Acknowledgements. Authors thank the providers of the various products made freely available through the internet that were used in the paper. A. Mouchet provided constructive comments during the early stages of manuscript elaboration, A. Barth and A. Alvera Azcarate helped with data analysis of Fig. 7, R. Matear and three anonymous reviewers provided constructive comments on the previous version of the paper. This work received financial support from the Belgian Federal Science Policy Office under the Belgian research on carbon uptake in the Antarctic Ocean (BELCANTO) -I, -II, and -III projects (contracts no. A4/DD/B14, EV12/7E, and SD/CA/03A), the Australian Climate Change Science Program of the Department of Environment and Water Resources, the Antarctic Climate and Ecosystems Cooperative Research Centre, Institut Polaire Français Paul Emile Victor, Institut National des Sciences de l'Univers, and Institut Pierre Simon Laplace, contributes to SOLAS.BE (contract no. OA/00/025), and to EU IP-CARBOOCEAN (contract no. 511176). AVB is a research associate at the Fonds National de la Recherche Scientifique (FNRS).

Edited by: C. Slomp

\section{References}

Bates, N. R.: Interannual variability of the oceanic $\mathrm{CO}_{2}$ sink in the subtropical gyre of the North Atlantic Ocean over the last 2 decades, J. Geophys. Res., 112, C09013, doi:10.1029/2006JC003759, 2007.

Behera, S. K. and Yamagata, T.: Subtropical SST dipole events in the southern Indian Ocean, Geophys. Res. Let., 28(2), 327-330, 2001.

Belkin, I. M. and Gordon, A. L.: Southern Ocean fronts from the Greenwich meridian to Tasmania, J. Geophys. Res., 101(C2), 3675-3696, 1996. 
Bopp, L., Monfray, P., Aumont, O., Dufresne, J. L., Le Treut, H., Madec, G., Terray, L., and Orr, J. C.: Potential impact of climate change on marine export production, Global Biogeochem. Cy., 15(1), 81-99, 2001.

Boyd, P. W., Crossley, A. C., DiTullio, G. R., Griffiths, F. B., Hutchins, D. A., Queguiner, B., Sedwick, P. N., and Trull T. W.: Control of phytoplankton growth by iron supply and irradiance in the subantarctic Southern Ocean: Experimental results from the SAZ Project, J. Geophys. Res., 106(C12), 31 573-31 583, 2001.

Brévière, E., Metzl, N., Poisson, A., and Tilbrook, B.: Changes of the oceanic $\mathrm{CO}_{2}$ sink in the Eastern Indian sector of the Southern Ocean, Tellus B, 58(5), 438-446, 2006.

Brix, H., Gruber, N., and Keeling, C. D.: Interannual variability of the upper ocean carbon cycle at station ALOHA near Hawaii, Global Biogeochem. Cy., 18, GB4019, doi:10.1029/2004GB002245, 2004.

Cai, W., Shi, G., Cowan, T., Bi, D., and Ribbe J.: The response of the Southern Annular Mode, the East Australian Current, and the southern mid-latitude ocean circulation to global warming, Geophys. Res. Lett., 32, L23706, doi:10.1029/2005GL024701, 2005.

Condie, S. A. and Dunn, J. R.: Seasonal characteristics of the surface mixed layer in the Australasian region: implications for primary production regimes and biogeography, Mar. Freshwater Res., 57, 569-590, 2006.

Copin-Montégut, C.: A new formula for the effect of temperature on the partial pressure of carbon dioxide in seawater, Mar. Chem., 25(1), 29-37, 1988.

Copin-Montégut, C.: A new formula for the effect of temperature on the partial pressure of carbon dioxide in seawater, Corrigendum, Mar. Chem., 27(1-2), 143-144, 1989.

Corbière, A., Metzl, N., Reverdin, C., and Takahashi, T.: Interannual and decadal variability of the oceanic carbon sink in the North Atlantic subpolar gyre, Tellus B, 59(2), 168-178, 2007.

Dore, J. E., Lukas, R., Sadler, D. W., and Karl, D. M.: Climatedriven changes to the atmospheric $\mathrm{CO}_{2}$ sink in the subtropical North Pacific Ocean, Nature, 424(6950), 754-757, 2003.

Feely, R. A., Boutin, J., Cosca, C. E., Dandonneau, Y., Etcheto, J., Inoue, H. Y., Ishii, M., Le Quéré, C., Mackey, D. J., McPhaden, M., Metzl, N., Poisson, A., and Wanninkhof, R.: Seasonal and interannual variability of $\mathrm{CO}_{2}$ in the equatorial Pacific, DeepSea Res. II, 49(13-14), 2443-2469, 2002.

Feely, R. A., Takahashi, T., Wanninkhof, R., Mcphaden, M. J., Cosca, C. E., Sutherland, S. C., and Carr, M. E.: Decadal variability of the air-sea $\mathrm{CO}_{2}$ fluxes in the equatorial Pacific Ocean, J. Geophys. Res., 111(C8), C08S90, doi:10.1029/2005JC003129, 2006.

Frankignoulle, M., Borges, A. V., and Biondo, R.: A new design of equilibrator to monitor carbon dioxide in highly dynamic and turbid environments, Water Res., 35(5), 1344-1347, 2001.

Goyet, C., Beauverger, C., Brunet, C., and Poisson, A.: Distribution of carbon dioxide partial pressure in surface waters of the Southwest Indian Ocean, Tellus B, 43(1), 1-11, 1991.

Gruber, N., Keeling, C. D., and Bates, N. R.: Interannual variability in the North Atlantic Ocean carbon sink, Science, 298(5602), 2374-2378, 2002.

Hall, A. and Visbeck, M.: Synchronous variability in the southern hemisphere atmosphere, sea ice, and ocean resulting from the annular mode, J. Climate, 15(21), 3043-3057, 2002.
Hamilton, L. J.: Structure of the Subtropical Front in the Tasman Sea, Deep-Sea Res. I, 53(12), 1989-2009, 2006.

Harris, G., Nilsson, C., Clementson, L., and Thomas, D.: The water masses of the east-coast of Tasmania - seasonal and interannual variability and the influence on phytoplankton biomass and productivity, Aust. J. Mar. Freshwater. Res., 38(5), 569-590, 1987.

Harris, G. P., Griffiths, F. B., Clementson, L. A., Lyne, V., and Vanderdoe, H.: Seasonal and interannual variability in physical processes, nutrient cycling and the structure of the food-chain in tasmanian shelf waters, J. Plankton Res., 13(S1), 109-131, 1991.

Hartmann, D. L. and Lo, F.: Wave-driven zonal flow vacillation in the Southern Hemisphere, J. Atmos. Sci., 55(8), 1303-1315, 1998.

Inoue, H. Y. and Ishii, M.: Variations and trends of $\mathrm{CO}_{2}$ in the surface seawater in the Southern Ocean south of Australia between 1969 and 2002, Tellus B, 57(1), 58-69, 2005.

Jabaud-Jan, A., Metzl, N., Brunet, C., Poisson, A., and Schauer, B.: Interannual variability of the carbon dioxide system in the southern Indian Ocean $\left(20^{\circ} \mathrm{S}-60^{\circ} \mathrm{S}\right)$ : The impact of a warm anomaly in austral summer 1998, Global Biogeochem. Cy, 18(1), GB1042, doi:10.1029/2002GB002017, 2004.

Kalnay, E., Kanamitsu, M., Kistler, R., Collins, W., Deaven, D., Gandin, L., Iredell, M., Saha, S., White, G., Woollen, J., Zhu, Y., Chelliah, M., Ebisuzaki, W., Higgins, W., Janowiak, J., Mo, K. C., Ropelewski, C., Wang, J., Leetmaa, A., Reynolds, R., Jenne, R., and Joseph, D.: The NCEP/NCAR 40-year reanalysis project, B. Am. Meteorol. Soc., 77(3), 437-471, 1996.

Körtzinger, A., Mintrop, L., Wallace, D. W. R., Johnson, K. M., Neill, C., Tilbrook, B., Towler, P., Inoue, H. Y., Ishii, M., and Shaffer, G.: The international at-sea intercomparison of $\mathrm{fCO}_{2}$ systems during the R/V Meteor Cruise 36/1 in the North Atlantic Ocean, Mar. Chem., 72(2-4), 171-192, 2000.

Le Quéré, C., Orr, J. C., Monfray, P., Aumont, O., and Madec, $\mathrm{G}$. : Interannual variability of the oceanic sink of $\mathrm{CO}_{2}$ from 1979 through 1997, Global Biogeochem. Cy., 14(4), 1247-1265, 2000.

Le Quéré, C., Bopp, L., and Tegen, I.: Antarctic circumpolar wave impact on marine biology: A natural laboratory for climate change study, Geophys. Res. Let., 29(10), 1407, 10.1029/2001GL014585, 2002.

Le Quéré, C., Aumont, O., Monfray, P., and Orr, J.: Propagation of climatic events on ocean stratification, marine biology, and $\mathrm{CO}_{2}$ : Case studies over the 1979-1999 period, J. Geophys. Res., 108(C12), 3375, doi:10.1029/2001JC000920, 2003.

Le Quéré, C., Rödenbeck, C., Buitenhuis, E.T., Conway, T. J., Langenfelds, R., Gomez, A., Labuschagne, C., Ramonet, M., Nakazawa, T., Metzl, N., Gillett, N., Heimann, M.: Saturation of the Southern Ocean $\mathrm{CO}_{2}$ sink due to recent climate change, Science, 316(5832), 1735-1738, 2007

Lefèvre, N., Watson, A. J., Olsen, A., Ríos, A. F., Pérez, F. F., and Johannessen, T.: A decrease in the sink for atmospheric $\mathrm{CO}_{2}$ in the North Atlantic, Geophys. Res. Let., 31(7), L07306, doi:10.1029/2003GL018957, 2004.

Lenton, A., and Matear, R. J.: Role of the Southern Annular Mode (SAM) in Southern Ocean $\mathrm{CO}_{2}$ uptake, Global Biogeochem. Cy., 21, GB2016, doi:10.1029/2006GB002714, 2007.

Lenton, A., Matear, R. J., and Tilbrook, B.: Observational strategy to constrain the annual air-sea flux of $\mathrm{CO}_{2}$ in the Southern Ocean, Global Biogeochem. Cy., 20, GB4010, doi:10.1029/GB002620, 
2006.

Li, Z. X.: Influence of Tropical Pacific El Niño on the SST of the Southern Ocean through atmospheric bridge, Geophys. Res. Let., 27(21), 3505-3508, 2000.

Lovenduski, N. S. and Gruber, N.: Impact of the Southern Annular Mode on Southern Ocean circulation and biology, Geophys. Res. Let., 32(11), L11603, doi:10.1029/2005GL022727, 2005.

Lovenduski, N. S., Gruber, N., Doney, S. C., and Lima, I. D.: Enhanced $\mathrm{CO}_{2}$ outgassing in the Southern Ocean from a positive phase of the Southern Annular Mode, Global Biogeochem. Cy., 21, GB2026, doi:10.1029/2006GB002900, 2007.

Louanchi, F., Metzl, N., and Poisson, A.: Modelling the monthly sea surface $\mathrm{fCO}_{2}$ fields in the Indian Ocean, Mar. Chem., 55(34), 265-279, 1996.

Louanchi, F. and Hoppema, M.: Interannual variations of the Antarctic Ocean $\mathrm{CO}_{2}$ uptake from 1986 to 1994, Mar. Chem., 72(2-4), 103-114, 2000.

Matear, R. J. and Hirst, A. C.: Climate change feedback on the future oceanic $\mathrm{CO}_{2}$ uptake, Tellus B, 51(3), 722-733, 1999.

Metzl, N., Beauverger, C., Brunet, C., Goyet, C., and Poisson, A.: Surface water carbon dioxide in the southwest Indian sector of the Southern Ocean: A highly variable $\mathrm{CO}_{2}$ source/sink region in summer, Mar. Chem., 35(1-2), 85-95, 1991.

Metzl, N., Poisson, A., Louanchi, F., Brunet, C., Schauer, B., and Brès, B.: Spatio-temporal distribution of air-sea fluxes of $\mathrm{CO}_{2}$ in the Indian and Antarctic Ocean, Tellus B, 47(1-2), 56-69, 1995.

Metzl, N., Louanchi, F., and Poisson, A.: Seasonal and interannual variations of sea surface carbon dioxide in the subtropical Indian Ocean, Mar. Chem., 60(1-2), 131-146, 1998.

Metzl, N., Tilbrook, B., and Poisson, A.: The annual $\mathrm{fCO}_{2}$ cycle and the air-sea $\mathrm{CO}_{2}$ flux in the sub-Antarctic Ocean, Tellus B, 51(4), 849-861, 1999.

Metzl, N., Brunet,C., Jabaud-Jan, A., Poisson,A., and Schauer,B.: Summer and winter air-sea $\mathrm{CO}_{2}$ fluxes in the Southern Ocean, Deep-Sea Res. I, 53(9), 1548-1563, 2006.

Midorikawa, T., Ishii, M., Nemoto, K., Kamiya, H., Nakadate, A., Masuda, S., Matsueda, H., Nakano, T., and Inoue, H.Y.: Interannual variability of winter oceanic $\mathrm{CO}_{2}$ and air-sea $\mathrm{CO}_{2}$ flux in the western North Pacific for 2 decades, J. Geophys. Res., 111(C7), L05612, doi:10.1029/2004GL021952, 2006.

Morrow, R., Valladeau, G., and Sallee, J.-B.: Observed subsurface signature of Southern Ocean sea level rise, Prog. Oceanogr., in press, 2007.

Poisson, A., Metzl, N., Brunet, C., Schauer, B., Brès, B., Ruiz-Pino, D., and Louanchi, F.: Variability of sources and sinks of $\mathrm{CO}_{2}$ in the Western Indian and Southern Oceans during the year 1991, J. Geophys. Res., 98(C12), 22 759-22 778, 1993.

Reynolds, R. W., Rayner, N. A., Smith, T. M., Stokes, D. C., and Wang, W. Q.: An improved in situ and satellite SST analysis for climate, J. Climate, 15(13), 1609-1625, 2002.

Ridgway, K. R.: Long-term trend and decadal variability of the southward penetration of the East Australian Current, Geophys. Res. Lett., 34, L13613, doi:10.1029/2007GL030393, 2007.

Rintoul, S. R. and Sokolov, S.: Baroclinic transport variability of the Antarctic Circumpolar Current south of Australia (WOCE repeat section SR3), J. Geophys. Res., 106(C2), 2815-2832, 2001.

Rintoul, S. R. and Trull, T. W.: Seasonal evolution of the mixed layer in the Subantarctic Zone south of Australia, J. Geophys. Res., 106(C12), 31 447-31 462, 2001.
Roemmich, D., Gilson, J., Davis, R., Sutton, P., Wijffels, S., and Riser, S.: Decadal spinup of the South Pacific Subtropical Gyre, J. Phys. Oceanogr., 37, 162-173, 2007.

Sabine, C. L., Feely, R. A., Key, R. M., Lee, K., Bullister, J. L., Wanninkhof, R., Wong, C. S., Wallace, D. W. R., Tilbrook, B., Millero, F. J., Peng, T.-H., Kozyr, A., Ono, T., and Rios, A. F.: The oceanic sink for anthropogenic $\mathrm{CO}_{2}$, Science, 305(5682), 367-371, 2004.

Sigman, D. M. and Boyle, E. A.: Glacial/interglacial variations in atmospheric carbon dioxide, Nature, 407(6806), 859-869, 2000.

Smith, W. H. F. and Sandwell, D. T.: Global sea floor topography from satellite altimetry and ship depth soundings, Science, 277(5334), 1956-1962, 1997.

Sokolov, S. and Rintoul, S.: Structure of the Southern Ocean fronts at $140^{\circ}$ E, J. Mar. Syst., 37(1), 151-184, 2002.

Takahashi, T., Sutherland, S. C., Sweeney, C., Poisson, A., Metzl, N., Tilbrook, B., Bates, N. R., Wanninkhof, R., Feely, R. A., Sabine, C., Olafsson, J., and Nojiri, Y.: Global sea-air $\mathrm{CO}_{2}$ flux based on climatological surface ocean $\mathrm{pCO}_{2}$, and seasonal biological and temperature effects, Deep-Sea Res. II, 49(9-10), 1601-1622, 2002.

Takahashi, T., Sutherland, S. C., Feely, R. A., and Wanninkhof, R.: Decadal change of the surface water $\mathrm{pCO}_{2}$ in the North $\mathrm{Pa}-$ cific: A synthesis of 35 years of observations, J. Geophys. Res., 111(C7), C07S05, doi:10.1029/2005JC003074, 2006.

Thompson, D. and Wallace, J.: Annular modes in the extratropical circulation. Part I. Month to-month variability, J. Climate, 13, 1000-1016, 2000.

Toggweiler, J. R.: Variation of atmospheric $\mathrm{CO}_{2}$ by ventilation of the ocean's deepest water, Paleoceanography, 14(5), 571-588, 1999.

Toggweiler, J. R., Russell, J. L., and Carson, S. R.: Midlatitude westerlies, atmospheric $\mathrm{CO}_{2}$, and climate change during the ice ages, Paleoceanography, 21, PA2005, doi:10.1029/2005PA001154, 2006.

Verdy, A., Marshall, J., and Czaja, A.: Sea surface temperature variability along the path of the Antarctic Circumpolar Current, J. Phys. Oceanogr., 36, 1317-1331, 2006.

Verdy, A., Dutkiewicz, S., Follows, M. J., Marshall, J., and Czaja, A.: Carbon dioxide and oxygen fluxes in the Southern Ocean: Mechanisms of interannual variability, Global Biogeochem. Cy., 21, GB2020, doi:10.1029/2006GB002916, 2007.

Wanninkhof, R.: Relationship between wind speed and gas exchange over the ocean, J. Geophys. Res., 97(C5), 7373-7382, 1992.

Watson, A. J. and Naveira Garabato, A. C.: The role of Southern Ocean mixing and upwelling in glacial-interglacial atmospheric $\mathrm{CO}_{2}$ change, Tellus B, 58(1), 73-87, 2006.

Weiss, R. F.: Carbon dioxide in water and seawater: the solubility of a non-ideal gas, Mar. Chem., 2(3), 203-215, 1974.

Weiss, R. F. and Price, B. A.: Nitrous oxide solubility in water and seawater, Mar. Chem., 8(4), 347-359, 1980. 